\title{
STUDI TENTANG PENYAKIT BAKTERIAL PADA IKAN KERAPU
}

\author{
Isti Koesharyani*)dan Zafran*)
}

\begin{abstract}
ABSTRAK
Upaya perbenihan ikan kerapu yang dilakukan di Loka Penelitian Perikanan Pantai Gondol Bali, dihadapkan pada masalah pemeliharaan induk yang rentan terhadap penyakit, antara lain adanya infeksi bakteri. Penelitian ini bertujuan untuk mengetahui jenis bakteri penyebab penyakit pada induk ikan kerapu. Satu isolat bakteri telah berhasil diisolasi dari organ ginjal ikan kerapu lumpur, Epinephelus coioides sakit. Isolat tersebut dapat tumbuh baik pada media Thiosulphate Citrate Bile Salt Sucrose Agar (TCBSA) dengan warna koloni kuning dan bakteri tersebut sensitif terhadap antibiotik klorampenikol dan oksitetrasiklin, tetapi kebal terhadap ampisilin dan eritromisin. Bakteri ini dapat diklasifikasikan ke dalam genus Vibrio sp. Hasil uji patogenisitas terhadap ikan kerapu batu, E. bontoides sehat menunjukkan bahwa kepadatan $10^{7}$ $\mathrm{cfu} / \mathrm{mL}$ ternyata dapat menyebabkan kematian total dalam waktu 24 jam.
\end{abstract}

\section{ABSTRACT: Study on bacterial diseases of grouper fishes. By: Isti Koesharyani and Zafran}

A crucial problem faced by Gondol Research Station for Coastal Fisheries-Bali in the breeding of grouper fish is the susceptibility of the broodstock against bacterial diseases. The study was aimed to isolate and characterize bacteria from infected grouper. Bacteria isolated from the kidney of diseased fish, Epinephelus coioides grew well at Thiosulphate Citrate Bile Salt Sucrose Agar (TCBSA) giving yellow colony, the bacteria was sensitive to antibiotics such as chloramphenicol and oxytetracycline, but resistance to amphicyline and erytromicine. The bacteria was identified as Vibrio sp. Pathogenicity test by intramuscular injection at density of $10^{7} \mathrm{cfu} / \mathrm{mL}$ into healthy fish E. bontoides resulted in total mortality within 24 hours.

\section{KEYWORDS: Bacterial diseases, grouper.}

\section{PENDAHULUAN}

Ikan kerapu merupakan komoditas yang mempunyai nilai ekonomis tinggi, dan akhirakhir ini permintaan kerapu hidup untuk konsumsi semakin meningkat.

Sejalan dengan permintaan pasar yang cukup tinggi, di Loka Penelitian Perikanan Pantai Gondol Bali sedang dikembangkan usaha perbenihan ikan kerapu seperti kerapu tikus Cromileptes altivelis, kerapu lumpur Ephinephelus coioides dan kerapu sunu Plectropoma sp. Tetapi dalam pembenihan ikan kerapu masih dihadapi berbagai masalah, di antaranya adalah penyakit yang menyerang/menginfeksi induk kerapu di dalam wadah budidaya. Masalah ini harus segera diatasi karena kesehatan induk merupakan hal yang sangat penting agar dapat menghasilkan benih yang berkualitas.
Mikroorganisme seperti virus, bakteri atau parasit merupakan penyebab penyakit yang sering ditemukan dalam pembenihan atau budidaya ikan (Leong, 1994; Bessie, 1988; Chua et al., 1994; Saeed, 1995). Kasus penyakit bakterial pada ikan kerapu E. salmoides disebabkan oleh adanya infeksi bakteri Vibrio sp. dan dapat bersifat patogen ataupun hanya penyebab sekunder (Bessie, 1988 dan Wong et al. dalam Wong et al., 1990). Sedangkan pada kerapu E. tauvina kasus penyakit dapat disebabkan oleh bakteri Vibrio harveyi (Saeed, 1995) atau Pseudomonas sp. berupa peradangan pada kulit (Nash et al., 1987).

Berdasarkan referensi tersebut di atas maka dilakukan penelitian tentang penyakit bakterial pada ikan kerapu lainnya dengan tujuan mengetahui penyebab penyakit dan mengidentifikasi serta menguji kepekaannya terhadap antibiotik.

\footnotetext{
Peneliti pada Loka Penelitian Perikanan Pantai Gondol - Bali
} 


\section{BAHAN DAN METODE}

\section{Pembuatan dan Karakterisasi Isolat Bakteri}

Dari bagian internal organ ginjal dan hati ikan kerapu lumpur $E$. coioides yang sakit dilakukan isolasi bakteri dengan menggunakan media Tryptone Soya Agar (TSA) dan Thiosulphate Citrate Bile Salt Sucrose Agar (TCBSA) kemudian diinkubasikan pada suhu $26-30^{\circ} \mathrm{C}$ selama 24-48 jam. Pemurnian terhadap bakteri yang tumbuh dominan pada setiap jenis media dilakukan dengan menggunakan media Marine Agar (MA). Hasil pemurnian bakteri ini selanjutnya digunakan sebagai bahan uji. Identifikasi isolat bakteri dilakukan berdasarkan acuan Lee \& Donovan (1985); Holt et al. (1994) dan Cowan \& Steel's (1993).

\section{Patogenisitas Bakteri}

Isolat bakteri uji dibiakkan dalam media MA yang diinkubasikan selama 18.24 jam pada suhu $26^{0} \mathrm{C}$, kemudian dipanen menggunakan air laut steril. Kepadatan bakteri $10^{8} \mathrm{cfu} / \mathrm{mL}$ ditentukan berdasarkan McFarland equivalence turbidity standard 1.0 setara dengan kepadatan bakteri $10^{8} \mathrm{cfu} / \mathrm{mL}$. Selanjutnya isolat bakteri tersebut diencerkan secara bertingkat sehingga didapat kepadatan bakteri berbeda $\left(10^{8} ; 10^{7} ; 10^{6}\right.$ dan $10^{5}$ $\mathrm{cfu} / \mathrm{mL}$ ) kemudian digunakan sebagai bahan infeksi, yaitu dengan cara menyuntikkan intramuskular sebanyak 0,05 mL/individu. Ikan kontrol disuntik dengan air laut steril dengan jumlah yang sama. Rancangan perlakuan uji patogenisitas bakteri adalah diskriptif. Ikan uji yang digunakan adalah kerapu batu, Epinephelus bontoides yang mempunyai bobot antara 10-20 gram, masing-masing sebanyak 10 ekor untuk setiap tingkat kepadatan bakteri. Pengamatan dilakukan terhadap mortalitas ikan uji setiap 12 jam selama empat hari dan melakukan reisolasi bakteri pada bagian ginjal dan luka bekas suntikan dari ikan uji yang lemah atau mati.

\section{Uji Sensitivitas terhadap Antibiotik}

Pengujian sensitivitas isolat bakteri terhadap antibiotik dilakukan secara in-vitro. Bakteri uji dioleskan secara merata pada lempengan media agar, lalu pada bagian permukaannya diletakkan lempeng antibiotik yang sudah mengandung antibiotik yang akan diuji yaitu oksitetrasiklin $(30 \mu \mathrm{g})$, klorampenikol $(30 \mu \mathrm{g})$, ampisilin $(10 \mu \mathrm{g})$ dan eritromisin $(15 \mu \mathrm{g})$, diproduksi oleh Oxoid, Unipath Limited, Besingstoke, Hampshire, UK., kemudian diinkubasikan selama 24 jam pada suhu $26^{\circ} \mathrm{C}$, dosis antibiotik yang digunakan disesuaikan dengan ketersediaan di pasaran. Tingkat sensitivitas ditentukan melalui pengukuran zona penghambatan yang diakibatkan oleh masing-masing antibiotik uji.

\section{HASIL DAN PEMBAHASAN}

\section{Isolasi dan Identifikasi Isolat Bakteri}

Isolat bakteri dominan diisolasi dari organ ginjal ikan kerapu lumpur E. coioides seberat 800 gram yang sakit, yang berasal dari penampungan ikan yang berlokasi di Gondol, Bali. Umumnya bakteri yang ditemukan pada internal organ tidak terlalu banyak jenis atau variasinya, sehingga bila memang terdapat infeksi cenderung membentuk satu jenis bakteri dominan, lain dengan bakteri yang diisolasi dari bagian eksternal yang banyak dipengaruhi oleh bakteri lainnya. Selanjutnya isolat tersebut diberi kode GRS-9601 dan digunakan dalam penelitian ini (Tabel 1).

Dari hasil identifikasi bakteri GRS-9601 yang berpedoman pada Lee \& Donovan (1985), Holt et al. (1994) dan Cowan \& Steel's (1993) ternyata bakteri ini termasuk ke dalam genus Vibrio, ini dapat dilihat dari beberapa kesamaan karakter antara lain gram negatif, Cytochrome Oxidase positif dan sensitivitas terhadap Vibrio Static agent 0/129 $150 \mathrm{mg}$ (Tabel 2). Bakteri vibrio dapat bersifat patogen terhadap ikan, seperti bakteri $V$. harveyi yang ditemukan sebagai penyebab penyakit mata ikan bandeng di Filipina (Muroga et al., 1984), begitu juga pada kasus infeksi mata pada ikan common snook, Centropomus undecimalis yang disebabkan oleh infeksi bakteri $V$. harveyi (Kraxberger et al., 1990). Sedangkan kasus pada ikan kerapu menunjukkan bahwa bakteri dari genus Vibrio sp. hanya berperan dalam 'secondary infection' yang dapat timbul setiap waktu tergantung dari faktor lingkungan serta faktor lainnya (Saeed, 1995 dan Leong, 1994). 
Tabel 1. Pertumbuhan bakteri yang diisolasi dari ginjal dan hati pada media bakteri yang berbeda. Table 1. Growth of bacteria isolated from kidney and liver on different bacterial media.

\begin{tabular}{ccc}
\hline Organ dalam & Media tumbuh bakteri & Hasil \\
Internal organ & Bacterial Medium & Result \\
\hline Ginjal (Kidney) & TCBSA & + \\
Hati (Liver) & TSA & + \\
& TCBSA & - \\
& TSA & - \\
\hline
\end{tabular}

Tabel 2. Karakteristik bakteri GRS-9601 yang diisolasi dari ginjal ikan kerapu lumpur, E. coioides, dibandingkan dengan karakter bakteri Vibrio spp. dari Holt et al., 1994; Lee \& Donovan, 1985 dan Cowan \& Stell's, 1993.

Table 2. Characteristics of bacterium GRS-9601 isolated from kidney of brown-spotted grouper, $E$. coioides, compared to bacteria Vibrio spp. according to Holt et al., 1994; Lee \& Donovan, 1985 and Cowan \& Steel's, 1993.

\begin{tabular}{|c|c|c|c|c|c|c|}
\hline \multirow[t]{2}{*}{$\begin{array}{l}\text { Karakteristik } \\
\text { Characteristics }\end{array}$} & \multirow[t]{2}{*}{$\begin{array}{c}\text { Isolat GRS-9601 } \\
\text { Isolate } \\
\text { GRS-9601 }\end{array}$} & \multirow[t]{2}{*}{$\begin{array}{l}\text { Holt } \\
\text { et al., } \\
1994\end{array}$} & \multirow[t]{2}{*}{$\begin{array}{l}\text { Lee \& } \\
\text { Donovan, } \\
1985\end{array}$} & \multirow{2}{*}{$\begin{array}{l}\text { Cowan } \\
\text { \& } \\
\text { Steel's, } \\
1993\end{array}$} & \multicolumn{2}{|c|}{$\begin{array}{c}\text { Diisolasi } \\
\text { kembali dari } \\
\text { Reisolated from } \\
\end{array}$} \\
\hline & & & & & $\begin{array}{l}\text { Ginjal } \\
\text { Kidney }\end{array}$ & $\begin{array}{l}\text { Luka } \\
\text { Lesion }\end{array}$ \\
\hline Pewarnaan gram (Gram stain) & & - & - & - & - & - \\
\hline $\begin{array}{l}\text { Sitokrom oksidase (Cytochrome } \\
\text { oxidase) }\end{array}$ & + & + & + & + & + & + \\
\hline Katalase (Catalase) & + & $\mathrm{Nt}$ & $\mathrm{Nt}$ & + & + & + \\
\hline Cahaya (Luminescent) & - & d & $d$ & $d$ & - & - \\
\hline Gerakan (Swarming) & d & $\mathrm{d}$ & d & $\mathrm{d}$ & d & $\mathrm{d}$ \\
\hline Pertumbuhan pada TCBSA & $\mathrm{Y}$ & $\mathrm{Y} / \mathrm{G}$ & $\mathrm{Y} / \mathrm{G}$ & d & $\mathrm{Y}$ & $\mathrm{Y}$ \\
\hline \multicolumn{7}{|l|}{ Growth on TCBSA } \\
\hline \multicolumn{7}{|l|}{ Pertumbuhan pada $\mathrm{NaCl}$} \\
\hline \multicolumn{7}{|l|}{ Growth in $\mathrm{NaCl}$ : } \\
\hline$-\quad 0 \%$ & & - & - & - & - & - \\
\hline$-3 \%$ & + & + & + & $\mathrm{Nt}$ & + & + \\
\hline - $6 \%$ & + & + & d & + & + & + \\
\hline - $\quad 10 \%$ & - & $\mathrm{Nt}$ & d & $\mathrm{Nt}$ & - & - \\
\hline L-Arginin & - & d & - & $\cdot$ & - & - \\
\hline L-Lysin & + & d & + & + & + & + \\
\hline L-Ornithin & + & $d$ & $\mathrm{~d}$ & $\mathrm{~d}$ & + & + \\
\hline Hugh-Leifson (O-F) & $\mathrm{F}$ & $\mathrm{F}$ & $\mathrm{F}$ & $\mathrm{F}$ & $\mathrm{F}$ & $\mathrm{F}$ \\
\hline $\begin{array}{l}\text { Peka terhadap } 150 \mathrm{mg} \text { vibriotic } \\
\text { agent } 0 / 129 \text { (Sensitive to } \\
\text { vibriotic agent 0/129.150 mg) }\end{array}$ & $\mathrm{S}$ & $\mathrm{S}$ & $\mathrm{S}$ & $\mathrm{d}$ & $\mathrm{S}$ & $\mathrm{S}$ \\
\hline
\end{tabular}

d: Karakter berbeda antar spesies (Character differs from species to species); S: Peka (Sensitive); F: Fermentatif (Fermentative); Y: Kuning (Yollo ); (C: Hijau (Green); Nt: Tidak diuji (Not tested)

\section{Patogenisitas Bakteri}

Hasil uji patogenisitas bakteri yang diisolasi dari ikan kerapu lumpur, E. coioides terhadap ikan kerapu batu, E. bontoides sehat dapat dilihat pada Tabel 3 .
Dari hasil pengamatan (Tabel 3), ternyata bakteri GRS-9601 dengan jumlah kepadatan $10^{7}$ dan $10^{8} \mathrm{cfu} / \mathrm{mL}$ dapat mematikan seluruh hewan uji dalam waktu kurang dari 24 jam. Sebelum ikan uji mati terdapat tanda-tanda ikan menjadi lemas dan terdapat luka/iritasi pada bagian 
tempat penyuntikan. Hasil isolasi ulang bakteri dari ginjal dan luka bekas suntikan ikan uji yang baru mati ternyata didapat bakteri jenis yang sama. Adanya bakteri yang sama pada ginjal membuktikan bahwa ginjal mempunyai fungsi reticuloendothelial yaitu kemampuan suatu organ untuk menyerap (trapping) bakteria dari darah, di mana akumulasi bakteri yang diinjeksikan secara intramuskular lebih banyak ditemukan pada organ limpa dan ginjal daripada dalam organ hati (Secombes \& Manning dalam Saeed, 1995).

\section{Sensitivitas Bakteri terhadap Antibiotik}

Pengujian dilakukan dengan menggunakan lempeng antibiotik yaitu untuk mengetahui jenis antibiotik mana yang dapat digunakan dalam alternatif pengobatan atau penanggulangan baik melalui pakan maupun perendaman. Bakteri GRS-9601 ini sensitif terhadap antibiotik oksitetrasiklin $(30 \mu \mathrm{g})$ dan klorampenikol $(30 \mu \mathrm{g})$ dan tahan terhadap antibiotik ampisilin $(10 \mu \mathrm{g})$ dan eritromisin $(15 \mu \mathrm{g})$ yaitu dengan melihat luasan zona penghambatannya (Tabel 4). Untuk itu perlu diuji lagi tingkat sensitivitas bakteri terhadap ampisilin dan eritromisin dengan meng. gunakan konsentrasi yang lebih tinggi.

Walaupun daya hambat antara oksitetrasiklin dan klorampenikol sama, tetapi dalam alternatif pengobatan klorampenikol tidak dapat diaplikasikan karena antibiotik tersebut berbahaya bagi individu serta dapat menimbulkan resistensi terhadap bakteri. Sedangkan pengobatan dengan menggunakan oksitetrasiklin (OTC) yang dicampurkan dalam pakan dengan dosis 0,5 gram/ $\mathrm{kg}$ ikan dapat diaplikasikan dalam alternatif penyembuhan atau pengobatan adanya infeksi bakteri. Terapi dengan menggunakan OTC yang dicampurkan dalam pakan pernah diterapkan terhadap ikan kerapu E. tauvina yang terinfeksi oleh $V$. harveyi dan dapat menekan kematian (Saeed, 1995).

Tabel 3. Mortalitas ikan kerapu E. bontoides yang diinjeksi secara intramuskular dengan berbagai tingkat kepadatan bakteri GRS-9601.

Table 3. Mortality of E. bontoides fingerling intramuscularly injected with various densities of bacterium GRS-9601.

\begin{tabular}{ccccccc}
\hline $\begin{array}{c}\text { Konsentrasi bakteri } \\
\text { (Bacteria concentration) }\end{array}$ & $\begin{array}{c}\text { Jml. ikan mati tiap 12 jam } \\
\text { No. of fish died every 12 } \mathbf{h} \\
(\mathbf{n}=\mathbf{1 0})\end{array}$ & $\begin{array}{c}\text { Mortalitas } \\
\text { total (Total } \\
\text { mortality) } \\
\text { (\%) }\end{array}$ & $\begin{array}{c}\text { Isolasi ulang } \\
\text { Reisolation }\end{array}$ \\
\cline { 2 - 5 } & $\mathbf{0 - 1 2}$ & $\mathbf{1 2 - 2 4}$ & $\mathbf{2 4 - 3 6}$ & $\mathbf{3 6 - 9 6}$ & \\
\hline $10^{8}$ & 10 & - & - & - & 100 & + \\
$10^{7}$ & 6 & 4 & - & - & 100 & + \\
$10^{6}$ & 1 & 5 & 0 & 0 & 60 & + \\
$10^{5}$ & 0 & 1 & 0 & 0 & 10 & + \\
\hline
\end{tabular}

Tabel 4. Kepekaan bakteria GRS-9601 terhadap beberapa antibiotik secara in-vitro.

Table 4. In-vitro sensitivity test of bacterium GRS-9601 to several antibiotics.

\begin{tabular}{lcc}
\hline \multicolumn{1}{c}{$\begin{array}{c}\text { Jenis lempeng antibiotik } \\
\text { Antibiotics disk }\end{array}$} & $\begin{array}{c}\text { Zona penghambatan } \\
\text { Inhibition zone } \\
(\mathbf{m m})\end{array}$ \\
\hline Oksitetrasiklin (Oxytetracycline) & $(30 \mu \mathrm{g})$ & 35 \\
Klorampenikol (Chloramphenicol) & $(30 \mu \mathrm{g})$ & 35 \\
Ampisilin (Ampicyline) & $(10 \mu \mathrm{g})$ & 0 \\
Eritromisin (Erytromycine) & $(15 \mu \mathrm{g})$ & 11 \\
\hline
\end{tabular}




\section{KESIMPULAN}

1. Bakteri yang ditemukan pada ginjal ikan kerapu lumpur $E$. coioides sakit adalah bakteri dari genus Vibrio sp.

2. Isolat bakteri tersebut bersifat patogen pada kepadatan $10^{\top}-10^{4} \mathrm{cfu} / \mathrm{mL}$, dapat menyebabkan kematian total benih ikan kerapu batu $E$. bontoides (ukuran 10.20 gram) dalam waktu kurang dari 24 jam.

3. Bakteri ini sensitif terhadap antibiotik oksitetrasiklin $(30 \mu \mathrm{g})$ dan klorampenikol $(30 \mu \mathrm{g})$, tetapi tahan terhadap ampisilin $(10 \mu \mathrm{g})$ dan eritromisin $(15 \mu \mathrm{g})$.

\section{DAFTAR PUSTAKA}

Bessie, O. 1988. Characteristic of bacteria isolated from diseased grouper, Epin'phelus salmoides. Aquaculture, 73: 7-17.

Cowan and Steel's. 1993. Manual for identification of medical bacteria (Third eds.) Cambridge University press. $386 \mathrm{p}$.

,Chua, F.C.H., M.L. Ng.. J.J. Loo and J.Y. Wee. 1994. Investigation of outbreak of novel diseases, Sleepy Grouper Diseases', affecting the brown-spotted grouper, Epinephelus tauvina Forskal. Journal of Fish Diseases 17: 417-427.

Holt, J.G., N.R. Krieg, P.H.A. Sneath, J.T. Staley, S.T. Williams. 1993. Bergey's manual of determinative bacteriology. Ninth Edition. Williams \& Wilkins, Baltimore, USA.
Kraxberger-Beatty, T., D.J. Mc. Garey, H.J. Grier and D.V. Lim. 1990. Vibrio harveyi, an opportunistic pathogen of common snook, Centropomus underimalis (Bloch), held in captivity. Journal Fish Diseases. 13: 557-560.

Lee, J.V. and T.J. Donovan. 1985. Vibrio, Aeromonas and Plosiomonas. In C.H. Collins and J.M. Grange (eds.). Isolation and identification of microorganisms of medical and veterinary importance. Academic Press (Harcourt Brace Jovanovich, Publishers). p.13-33

Leong, T.S. 1994. Parasites and diseases of cultured marine finfish in South East Asia. School of Biological Science, University Sains Malaysia. 25 p.

Muroga, K., Gilda Lio-Po, C. Pitogo and R. Imada. 1984. Vibrio sp. isolated from milkfish (Chanoschanos) with opaque eyes. Fish Pathology. 19(2):81 87.

Nash, G., I.G. Anderson, M. Shariff and M.N. Shamsudin. 1987. Bacteriosis associated with epizootic in the giant sea perch, Lates calcalifer, and the estuarine grouper, Epinephelus tauvina, cage cultured in Malaysia. Aquaculture 67:105111.

Saeed. O. 1955. Association of Vibrio harveyi with mortalities in cultured marine fish in Kuwait. Aquaculture, 136:21-29.

Wong, S.Y., T.Y. Lee and T.S. Leong. 1990. Cross protection of Vibrio vaccines against various pathogenic Vibrio obtained from diseased grouper (Epinephelus salmoides). The second Asian Fisheries Forum. Manilla Phillipines. p.683-687. 